\title{
Using of Telomerase Enzyme in Urine as a Non invasive Marker for Cancer Bladder Detection
}

\author{
Azza A Hassan*, Fawzia A . El- Sheshtawey**, Seliem A. Seliem***, \\ Mohammed A. Abd El Salam\# \\ Departments of Clinical Pathology* , National Institute of Urology \& Nephrology-Cairo, \\ Clinical Pathology** \& Urology***- Faculty of Medicine for Girls-Al Azhar University, \\ Pathology\#-Cairo Faculty of Medicine
}

\begin{abstract}
Background: Urinary bladder cancer is one of the major health problem all over the world. Cystoscopy remains the gold standard for identifying bladder cancer but it is invasive and expensive, therefore, a simple, non invasive test for detecting bladder cancer would be helpful. Several biomarkers for bladder cancer have been used, but no single marker has been accurate and conclusive.

Aim: The current study aimed to measure telomerase enzyme in urine as a useful non invasive marker for detection of bladder cancer.

Methods : Forty eight patients ( 39 males and 9 females) were included, They are complaining of urinary symptoms and undergo cystoscopy with biopsy of bladder lesions and histopathological examination. They were divided into groups: Group I: 16 patients ( 11 males and 5 females) have benign urologic conditions. Group II: 32 patients (28 males and 4 females) have proven bladder cancer patients underwent transurethral resection of bladder tumor or cystoscopy with biopsy of bladder lesions. Also, 15 apparently healthy volunteers with matched age and sex with patients were served as a control group. All subjects were submitted to laboratory estimation of the following in urine: urinary creatinine, urine cytology, telomerase enzyme in urine by telomerase PCR and complete urine examination.

Results : The results of this study revealed that a highly significant increase in the frequency of cytolological positive cases for tumor cells in malignant group than each of benign group and healthy subjects, while no significant difference was detected between benign group and healthy subjects. The frequency of telomerase in urine was significantly higher in malignant group than each of benign group and healthy subjects, while no significant difference was detected between benign group and healthy subjects. The telomerase activity has sensitivity of $90.6 \%$ for diagnosis of cancer bladder with $93.7 \%$ for specificity and PPV was $96.6 \%$, NPV was $83.3 \%$ and diagnostic accuracy of $91.6 \%$. While, urine cytology gives a sensitivity of $68.8 \%$, specificity of $87.5 \%$, PPV of $91.6 \%$, NPV $58.3 \%$ and diagnostic accuracy of $75 \%$. When combined tests were used the sensitivity raised to $96,8 \%$, and specificity reached to $100 \%$, PPV was $96.6 \%$, NPV was $94.1 \%$ and diagnostic accuracy increased to $97.9 \%$.
\end{abstract}

Conclusion: the urinary assay of telomerase could be used as non invasive test to identify the bladder cancer patients and distinguish them from normal subjects and patients with benign tumor of urinary bladder. The low cost of this test may help to be implicated as non invasive screening of bladder cancer.

Key words : Cancer Bladder, Telomerase , PCR

\section{Introduction}

Several important risk factors have been identified for bladder cancer including cigarette smoking, exposure to chemicals and the presence of chronic inflammation like belharziasis (Boon \& Drijver, 1986). Bladder cancer has a high incidence matched by a tendency to recur, necessitating close and regular follow up (Saad et al., 2001). Although the incidence of cancer bladder is increasing, methods of diagnosis have changed little during the last few decades (Pirtskalaishvili et al., 1999). 
Cytoscopy and urine cytopathology identifies the presence of abnormal malignant cells, which are shed into the urine (Thomas et al., 1999). These methods are expensive, invasive, time consuming and have low sensitivity, however, its ability to detect low grade bladder cancer is limited (Saad et al., 2001). Researchers discovered markers with practical diagnostic potential among them are cytokeratines (Eissa et al., 2002), and molecular markers as telomerase enzyme (Muller ,2002).

Telomerase is an enzyme that adds specific DNA sequence repeats ("TTAGGG" in all vertebrates) to the $3^{\prime}$ ("three prime") end of DNA strands in the telomere regions, which are found at the ends of eukaryotic chromosomes. The telomeres contain condensed DNA material, giving stability to the chromosomes. The enzyme is a reverse transcriptase that carries its own RNA molecule, which is used as a template when it elongates telomeres, which are shortened after each replication cycle. There are some indicators that telomerase is of retroviral origin (Witzany, 2008).

Most normal cells do not possess telomerase mechanism, but almost all cancer cells acquire, to overcome their mortality and extend their lifespan (Granger et al., 2002). As divisions are being counted, events occur on the cellular and molecular level, which may either delay or hasten growth arrest. As humans age, a particular concern is the accumulation of events that lead to the progression of cancer (Granger et al., 2002).

The role of telomerase is to reconstitute the telomeres, such action is turned off in normal cells, however telomerase is activated in malignant cells making them immortal. Telomerase activity could be detected in most common cancers and thus could be used as a molecular marker in bladder cancer (Saad et al., 2001), where measurement of telomerase in the cell sediments from voided urine for diagnosis of bladder cancer is promising (Sanchini et al., 2004). The level of telomerase activity is generally influenced by the fraction of cells in the proliferative pool. Shortened telomeres and high telomerase activity almost always correlates with disease severity in hematologic neoplasia such as relapsed leukemia and high-grade lymphomas, indicating that measurement of telomere length and telomerase activity might be useful to monitor disease condition (Ohyashik et al., 2002).

This study aimed to assess usefulness of using a new molecular marker namely telomerase enzyme in urine as a non invasive marker in the detection of urinary bladder cancer as comparing to conventional urine cytology.

\section{Subjects and Methods}

Forty eight patients ( 39 males and 9 females) were included, they attending the outpatient clinic and inpatient ward of National Institute of Urology \& Nephrology and Urology department of $\mathrm{Al}$ Zahraa University Hospital, their ages ranged from 42-75 years. They were complaining of urinary symptoms and undergo cystoscopy with biopsy of bladder lesions and histopathological examination.

Also, 15 apparently healthy volunteers with matched age and sex with patients were served as a control group.

\section{The patients were divided into groups:}

Group I: 16 patients ( 11 males and 5 females) have benign urologic conditions.

Group II: 32 patients (28 males and 4 females) have proven bladder cancer patients underwent transurethral resection of bladder tumor or cystoscopy with biopsy of bladder lesions.

All subjects were submitted to the following laboratory investigations:

Serum sample for kidney function tests (urea, creatinine, serum sodium and potassium).

Urine collection and preparation: the voided urine samples (retained at least for 3 hours in the urinary bladder, but not the morning sample) were collected from all subjects into two sterile containers. One contained $20 \mathrm{ml}$ for urine cytology, the other container $10 \mathrm{ml}$ used for complete urine examination and urinary creatinine estimation and $50 \mathrm{ml}$ used to determination of telomerase enzyme activity 


\section{1- Detection of telomerase enzyme by PCR:}

Fifty $\mathrm{ml}$ of was centrifuged at 10000 $\mathrm{x} g$ for 10 minutes. The supernatant was removed and the precipitated urothelial cells pellet was suspended and washed with phosphate buffered saline (PBS) and_recentrifuged and the pelleted cells were stored at $-80{ }^{\circ} \mathrm{C}$ to be used in the telomerase PCR assay.

Telomerase enzyme activity in urine was detected by Telomerase PCR ELISA kit (Roche, Cat. no. 12013789001) supplied by (Roch diagnostic Gmbh-Germany). The kit is designed for highly qualitative detection of telomerase activity in cell extracts from cell cultures and other biological samples using telomeric repeat amplification protocol developed by Kim et al., (1994). It utilizes a biotinylated primer for immobilization within the ELISA microtiter plate and allows highly specific amplification of elongation products combined with non-radioactive detection following an ELISA protocol (Muller, 2002). Detection was done according to the manufacturer's instructions. In the first step telomerase adds telomeric repeats (TTAGGG) to the 3 ' end of the biotinlabeled synthetic Pl-TS-primer. In the second step, these elongation products are amplified by PCR using the primers P1-TS and $\mathrm{P} 2$, generating $\mathrm{PCR}$ products with the telomerase-specific 6 nucleotide increments. An aliquot of the PCR product is denaturated and hybridized to a digoxigenin-(DIG)-labeled, telomeric repeatspecific detection probe. The resulting product is immobilized via the biotin labeled primer to a streptavidin-coated microtiter plate. The immobilized PCR product is then detected with antibody against digoxigenin (anti-DIG-POD) that is conjugated to peroxidase. Finally, the probe is visualized by virtue of peroxidase metabolizing $\mathrm{TMB}$ to form a coated reaction product. Samples were regarded telomerase positive if the difference in absorbance readings at $450 \mathrm{~nm}$ and $690 \mathrm{~nm}$ was higher than 0.2 units.

\section{2- Complete urine examination:}

Macroscopic and microscopic examinations were done to assess the presence of RBCs, pus cells, crystals, albumin and casts .

3- Cytological examination of urine samples was performed according to Boon and Drijver (1986). Samples were centrifuged and the supernatants were completely discarded. The pellets were smeared on 3 smears and left for air drying, fixation was done then the smears were stained using Haematoxylin-Eosin stain.

\section{Statistical analysis:}

Data were coded and summarized using SPSS (statistical package for Social Sciences) version 12.0 for Windows. Qualitative variables were described using frequency and percentage. Comparison between groups was done using Chi square $\left(\mathrm{X}^{2}\right)$ test for qualitative variables To assess the diagnostic value of using parameters, the following indices were calculated: sensitivity, specificity, positive predictive value (PPV) which means the probability of diagnosis and negative predictive value (NPV) that is the probability of excluding the diagnosis. $\mathrm{P}$ value $<0.05$ was considered statistically significant.

\section{Results}

Tables (1) shows a highly significant increase in the frequency of cytolological positive cases for tumor cells $(\mathrm{p}<0.001)$ in malignant group than each of benign group $(\mathrm{p}<0.001)$ and healthy subjects $(\mathrm{p}<0.001)$, while no significant difference was detected between benign group and healthy subjects $(p>0.05)$. However, complete urine examination, kidney function tests, or urine creatinine revealed no significant difference between benign and malignant groups (data not mentioned in the table).

As regard the frequency of telomerase enzyme activity in urine, it was significantly higher in malignant group and each of benign group $(\mathrm{p}<0.001)$ and healthy subjects $(\mathrm{p}<0.001)$, while no significant difference was detected between benign group and healthy subjects $(p>0.05)$ (Table 2).

The telomerase activity has sensitivity of $90.6 \%$ for diagnosis of cancer bladder with $93.7 \%$ for specificity and PPV 
was $96.6 \%$, NPV was $83.3 \%$ and diagnostic accuracy of $91.6 \%$.

The urine examination for cytology gives sensitivity of $68.8 \%$, specificity of 87.5\%, PPV of $91.6 \%$, NPV $58.3 \%$ and diagnostic accuracy of $75 \%$.
When combined tests were used the sensitivity raised to $96,8 \%$, and specificity reached to $100 \%$, PPV was $96.6 \%$, NPV was $94.1 \%$ and diagnostic accuracy increased to $97.9 \%$ (Table 3).

Table (1) The frequency of urine cytology in the studied groups and controls

\begin{tabular}{|c|c|c|c|}
\hline & $\begin{array}{c}\text { Benign cases } \\
(\mathrm{No}=16)\end{array}$ & $\begin{array}{c}\text { Malignant cases } \\
(\mathrm{No}=32)\end{array}$ & $\begin{array}{c}\text { Healthy controls } \\
(\mathrm{No}=15)\end{array}$ \\
\hline $\begin{array}{c}\text { Urine Cytology: } \\
\text { +ve }\end{array}$ & $2(12.5 \%)$ & $22(68.8 \%)$ & $0(0 \%)$ \\
-ve & $14(87.5 \%)$ & $10(31.2 \%)$ & $15(100 \%)$ \\
\hline Test of significance & $\begin{array}{c}\mathrm{X}^{2}=15.6 \\
\mathrm{P}^{(\mathrm{a})}<0.001 * *\end{array}$ & $\begin{array}{c}\mathrm{X}^{2}=19.7 \\
\mathrm{P}^{(\mathrm{b})}<0.001 * *\end{array}$ & $\begin{array}{c}\mathrm{X}^{2}=2.4 \\
\mathrm{P}^{(\mathrm{c})}>0.05\end{array}$ \\
\hline
\end{tabular}

$\mathrm{P}^{(\mathrm{a})}=$ comparison between groups malignant and benign, $\mathrm{P}^{(\mathrm{b})}=$ comparison between groups malignant and control, $\mathrm{P}^{(\mathrm{c})}=$ comparison between groups benign and control.

Table (2) The frequency of telomerase activity in the studied groups and controls

\begin{tabular}{|c|c|c|c|}
\hline & $\begin{array}{c}\text { Benign cases } \\
(\mathrm{No}=16)\end{array}$ & $\begin{array}{c}\text { Malignant cases } \\
(\mathrm{No}=32)\end{array}$ & $\begin{array}{c}\text { Healthy controls } \\
(\mathrm{No}=15)\end{array}$ \\
\hline $\begin{array}{c}\text { Telomerase activity: } \\
\text { +ve }\end{array}$ & $\begin{array}{c}1(6.3 \%) \\
\text {-ve }\end{array}$ & $29(90.6 \%)$ & $0(0 \%)$ \\
$15(93.7 \%)$ & $3(9.4)$ & $15(100 \%)$ \\
\hline Test of significance & $\mathrm{X}^{2}=20.5$ & $\mathrm{X}^{2}=25.8$ & $\mathrm{X}^{2}=0.0$ \\
& $\mathrm{P}^{(\mathrm{a})}<0.001 * *$ & $\mathrm{P}^{(\mathrm{b})}<0.001 * *$ & $\mathrm{P}^{(\mathrm{c})}>0.05$ \\
\hline
\end{tabular}

$\mathrm{P}^{(\mathrm{a})}=$ comparison between groups malignant and benign, $\mathrm{P}^{(\mathrm{b})}=$ comparison between groups malignant and control, $\mathrm{P}^{(\mathrm{c})}=$ comparison between groups benign and control.

Table (3) The significance of using telomerase activity and urine cytology $(n=48)$

\begin{tabular}{|l|l|l|l|}
\hline Term & Telomerase activity & Urine Cytology & Combined tests \\
\hline Sensitivity & $90.6 \%$ & $68.8 \%$ & $96.8 \%$ \\
\hline Specificity & $93.7 \%$ & $87.5 \%$ & $100 \%$ \\
\hline PPV & $96.6 \%$ & $91.6 \%$ & $96.8 \%$ \\
\hline NPV & $83.3 \%$ & $58.3 \%$ & $94.1 \%$ \\
\hline Accuracy & $91.6 \%$ & $75 \%$ & $97.9 \%$ \\
\hline
\end{tabular}

$\mathrm{PPV}=$ positive predictive value, $\mathrm{NPV}=$ negative

predictive value.

\section{Discussion}

Bladder cancer is the second most common malignancy affecting the genitourinary system and is one of the most common tumors in Egypt (Sabaa et al., 2002), where the incidence of transitional cell carcinoma represent $37.9 \%$ from all histopathologic types.

Telomerase is an RNA dependant ribonucleoprotein complex that acts as a reverse transcriptase which utilizes sequence of its RNA component as a template for de novo synthesis of telomeric 
DNA sequences (Masutomi et al., 2000). Although cystoscopy is sensitive in the detection of bladder cancer, it is invasive, expensive and uncomfortable for patients. Urine cytology has been the most commonly used marker for transitional cell carcinoma, although useful cytology is hampered by subjectively among cytopathologist and relative insensitivity for moderate and well differentiated tumors (Burchardt et al., 2000). Currently, a variety of markers have been developed among of these, there are telomerase enzyme (Dettlaff-Pokora et al., 2005).

Forty eight patients were included in this study, they were divided into 2 groups, 16 patients have benign urologic conditions and 32 patients have proven bladder cancer patients as well as 15 healthy control subjects.

This study revealed that a highly significant increase in the frequency of cytolological positive cases for tumor cells in malignant group than each of benign group and healthy subjects, while no significant difference was detected between benign group and healthy subjects. Moreover, the frequency of telomerase activity in urine was significantly higher in malignant group than each of benign group and healthy subjects, while no significant difference was detected between benign group and healthy subjects. Also, Li et al., (2002) stated that the telomerase activity in urine of patients with urothelial carcinoma increased significantly as compared to the control group.

Dettlaff-Pokora et al., (2005) mentionned that $88 \%$ human bladder cancers had telomerase activity in the sediments from voided urine of patients with superficial bladder carcinoma. In case of muscleinvasive tumors, telomerase activity was found in $93 \%$ of urine sediments. Enzyme activity was not detected in control urine sediments. In contrast to all the previous results, a study done by Linn et al., (1997) showed that all urine samples of 12 patients with bladder cancer tested for telomerase activity were found to be negative. This could be explained by false negative results, as high protein concentration and Taq polymerase inhibitors may be present, also RNAase or proteases may degrade the RNA template or catalytic domain of the telomerase enzyme (Liu and Loughlin, 2000).

In the current study, telomerase activity give a sensitivity of $90.6 \%$ for diagnosis of cancer bladder with $93.7 \%$ for specificity and positive predictive value (PPV) was $96.6 \%$, negative predictive value (NPV) was $83.3 \%$ and diagnostic accuracy of $91.6 \%$. Comparable results were reported by some investigators, the sensitivity and specificity were $77 \%$ \& $85 \%$, respectively as reported by Eissa et al (2003), also a study reported by Glas et al., (2004) stated that telomerase sensitivity and specificity were $75 \%$ \& $86 \%$ respectively.

While, in our study, urine cytology gives a sensitivity of $68.8 \%$, specificity of $87.5 \%, \mathrm{PPV}$ of $91.6 \%$, NPV $58.3 \%$ and diagnostic accuracy of $75 \%$. In contrast to $\mathrm{Wu}$ et al., (2001) study, in which urine cytology only yielded a sensitivity of $31 \%$ in the detection of bladder cancer and the study done by Boman et al., (2002) in which cytology had $42 \%$ sensitivity at $97 \%$ specificity. The sensitivity of this study was higher than that reported by Eissa et al., (2002) where the sensitivity and specificity were $44 \%$ and $100 \%$ respectively for voided urine cytology. Urine cytology sensitivity was $13.3 \%$ as detected by Bartoletti et al., (2005), while the specificity reported for cytology was 94\% as stated by Van Rhijn et al. (2005).

Surprisingly in our study, when combined tests were used the sensitivity raised to $96,8 \%$, and specificity reached to $100 \%$, PPV was $96.6 \%$, NPV was $94.1 \%$ and diagnostic accuracy increased to $97.9 \%$.

Finally, it could be concluded that telomerase enzyme activity had the highest sensitivity and specificity for the diagnosis of bladder cancer than using of urine cytology. The using of combined markers give $100 \%$ specificity. The low cost of telomerase activity in urine may help to be implicated as non invasive screening of bladder cancer.

\section{References}

1. Bartoletti R, Dal Canto M, Cai T, Piazzini M, Travaglini F, Gavazzi A, Rizzo M (2005): Early diagnosis and 
monitoring of superficial transitional cell carcinoma by microsatellite analysis on urine sediment. Oncol Rep., 13(3):531-7.

2. Boman H, Hedelin H, Jacobsson S, Holmang S (2002): Newly diagnosed bladder cancer: the relationship of initial symptoms, degree of microhematuria and tumor marker status. J Urol.,168(5):1955-9.

3. Boon ME and Drijver JS (1986): Routine cytological staining techniques. Theoretical background and practice. pp. 16-32, 51-9118

4. Burchardt M, Burchardt T, Shabsigh A, De La Taille A, Benson MC and Sawczuk I (2000): Current concepts in biomarker technology for bladder cancer. Clin Chem ., 46: 595- 605.

5. Dettlaff-Pokora A, Matuszewski $M$ and Schlichtholz B (2005): Telomerase activity in urine sediments as a tool for noninvasive detection of bladder cancer.Cancer Lett., 222(1):83-88.

6. Eissa S, Swellam M, Sadek M, Mourad MS, Ahmady OE and Khalifa A (2002): Comparative evaluation of nuclear matrix protein, fibronectin, urinary bladder cancer antigen and voided urine cytology in the detection of bladder tumors. J Urol., 168:465-9.

7. Eissa S, Swellam M, El-Mosallamy H, Mourad MS, Hamdy N, Kamel A (2003): Diagnostic value of urinary molecular markers in bladder cancer.Anticancer Res., 23(5b):4347-4355.

8. Glas AS, Roos D, Deutekom M, Zwinderman AH, Bossuyt PM and Kurth KH (2004): Tumor markers in the diagnosis of primary bladder cancer. A systematic review. J Urol., 171(6 Pt 1):2383-4.

9. Granger MP, Wright WE, Shay JW (2002): Telomerase in cancer and aging. Crit Rev Oncol Hematol; 41 (1): 29-40.

10. Kim NW, Piatyszek MA, Prowse KR, Harley Wets MD and Ho PL (1994): Specific association of human telomerase activity with immortal cells and cancer. Science, 266:2011-2015.

11. Li Z, Kong C, Wang P, Liu X, Liu T (2002): Telomerase activity in urine in diagnosis and recurrence surveillance of urothelial carcinoma. Chin Med J., 115(11):1650-2.

12. Linn IF, Lango $M$ and Hallachm I (1997): Microsatalitte analysis and telomerase activity in archived and urine samples of bladder cancer patients. Int $\mathbf{J}$ Cancer, 74:625-629.
13. Liu BC and Loughlin KR (2000): Telomerase in human bladder cancer. Urol Clin .,(27), 115-123

14. Masutomi K, Kaneko S, Hayashi N, Yamashita T, Shirota Y, Kobayashi K, Murakami S (2000): Telomerase activity reconstituted in vitro with purified human telomerase reverse transcriptase and human telomerase RNA component. J Biol Chem ., 1;275(29):22568-73.

15. Muller M (2002): Telomerase: its clinical relevance in diagnosis of bladder cancer. Oncogene, 21(4):650- 655.

16. Ohyashiki JH; Sashida G; Tauchi T; Ohyashiki K (2002): Telomeres and telomerase in hematologic neoplasia. Oncogene;21(4):680-7.

17. Pirtskalaishvili G, Konety BR and Getzenberg RH (1999): Update on Urinebased markers for bladder cancer: how sensitive and specific are the new noninvasive tests? Postgrad Med., 106(6): 85-94.

18. Saad A, Hanbury DC, McNicholas TA, Boustead GB and Woodman AC (2001): The early detection and diagnosis of bladder cancer a critical review of option. Eur Urol., 39(6): 619.-633

19. Sabaa MA ,ELashry OM, Ismaeil M , Hazzaa S , Eid Mand Nayel EM (2002): A novel antiapoptosis gene, Survivin, expression in diagnosis of bladder cancer. Tanta MJ., 30(2): 341-351.

20. Sanchini MA, Bravaccini S, Medri L, Gunelli R, Nanni O, Monti F, Baccarani PC, Ravaioli A, Bercovich E, Amadori D, Calistri D (2004): Urine telomerase: an important marker in the diagnosis of bladder cancer. Neoplasia , 6(3):234-9.

21. Thomas L, Leyh H, Marberger $\mathbf{M}$, Bombardieri E Bassi P, and Pagano F (1999): Multicenter trial of the quantitative BTA trak assay in the detection of bladder cancer. Clinical Chemistry, 45 (4) 472- 477.

22. Van Rhijn BW, van der Poel HG, van der Kwast TH (2005): Urine markers for bladder cancer surveillance: a systematic review. Eur Urol .,47(6):736-48.

23. Witzany, G. (2008). "The Viral Origins of Telomeres and Telomerases and their Important Role in Eukaryogenesis and Genome Maintenance". Biosemiotics , 1: 191-206.

24. Wu WJ, Liu LT, Huang CH, Chang SF, Chang LL (2001): Telomerase activity in human bladder tumors and bladder washing specimens. Kaohsiung J Med Sci. ,17 (12): 602-9 


\section{استخدام إنزيم تليموريز بالبول كدلاله للكشف عن سرطان المثانة}

عزة عبد الجليل حسن* فوزية عبد السميع الشيشتاوى***. سليم احمد

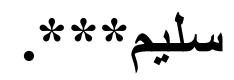

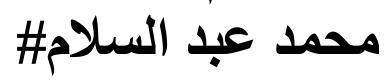

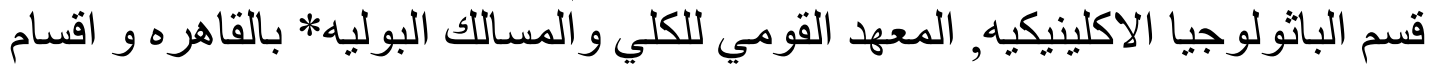

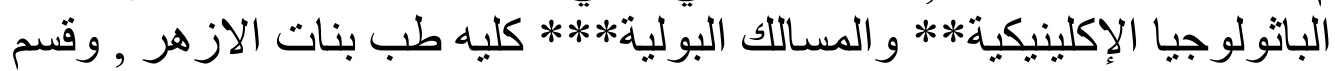
الباثولوجي\# بطب القاهره

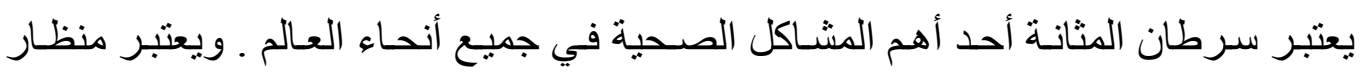

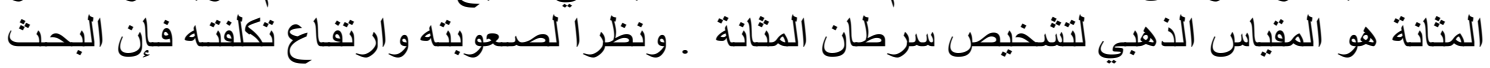

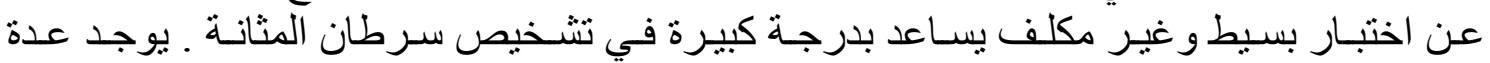

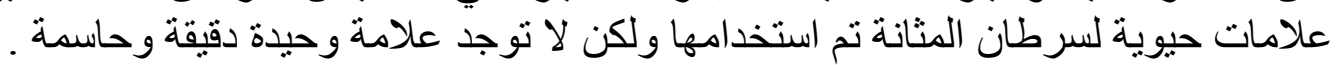

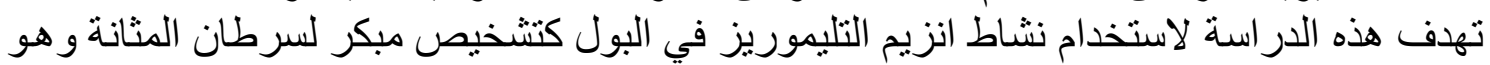

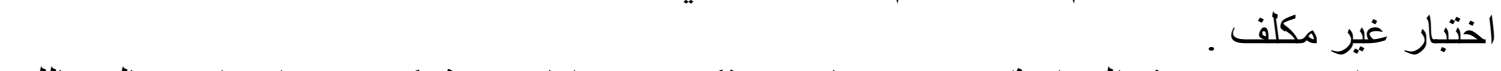
وقد تضمنت هذه الدراسة 48 مريضا (39 ذكور و 9 إناث ) يشتكون من اعر اض بالمسالك

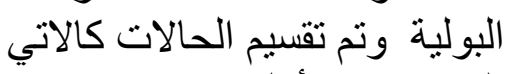

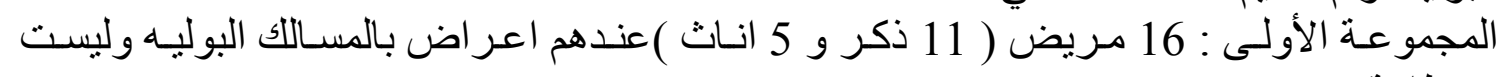
سرطانية المجية المجموعة الثانية : 32 ( 28 ذكر و 4 اناث اثن ) يعانون من سرطان المثانة

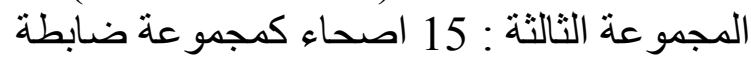
تم اختبار البول و كريتنين البول ونوع الخلايا ونثاط التليموريز بواسطة سلسله التفاعل الجزيئي

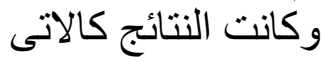

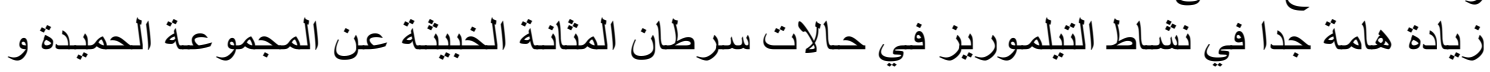

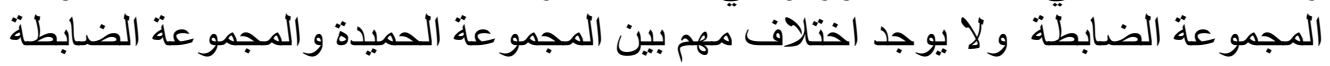

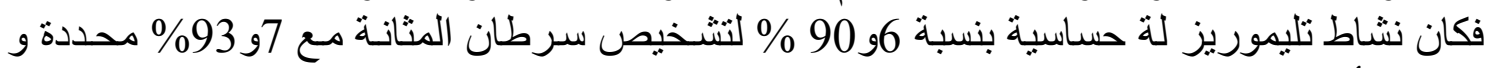

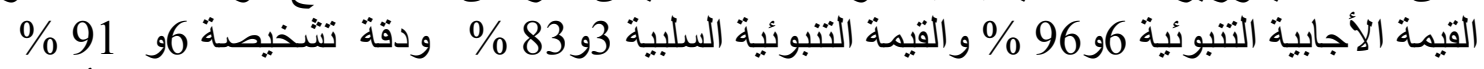

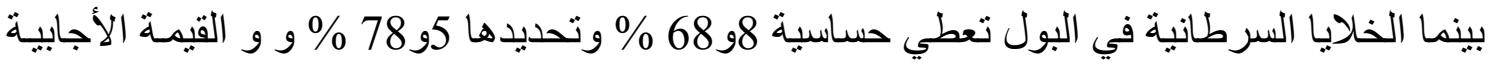

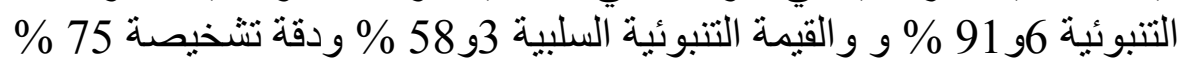
و عند قياس نشاط التليموريز و والخلايـا السرطانية في البول معا ارتفعت الحساسية فى التثخيص

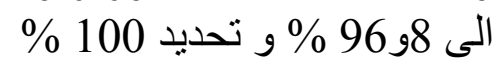

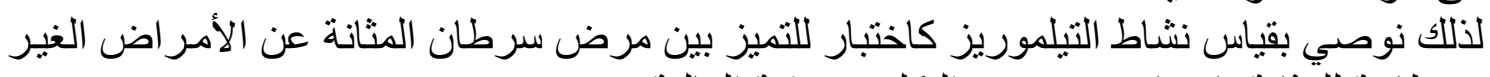

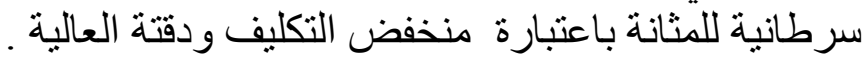

